\title{
Study on Training System and Continuous Improving Mechanism for Mechanical Engineering
}

\author{
Guojin Chen* and Jianhui Zhang
}

\author{
Mechanical Department, Hangzhou Dianzi University, Hangzhou, 310018, China
}

\begin{abstract}
In view of the Zhejiang province industry characteristics and the demand for talents in the field of mechanical engineering, combined with the advantages, the orientation for training talent with the coordinated development of "knowledge, ability and quality" is put forward. This paper analyzes the training target and plan in mechanical engineering, sets the practice links to enhance the students' engineering consciousness, practical ability and innovation ability, and establishes quality monitoring and evaluation system. On the basis of the intelligent manufacturing system, the intelligent plant experimental system based on industry 4.0 is developed. Taking the training target as the starting point, the complete system with the closed loops is formed, which is composed of students, graduation requirements, continuous improvements, curriculum programs, and supporting conditions. A mechanism for continuous improvement is developed, due to which a healthy cycle comes into being. Therefore the quality of engineering education can be greatly improved.
\end{abstract}

Keywords: Continuous improving mechanism, mechanical engineering, quality monitoring and evaluation, training system.

\section{INTRODUCTION}

The professional certification of engineering education refers to the international quality guarantee system of the engineering education, which is an important foundation for the international mutual recognition of engineering education and engineer qualification. The basic idea of the professional certification for engineering education involves the following aspects: the first is to stress on all of the students' objectives. The students are the main service objects. The satisfaction of the students and the employing units for the university or professional services are an important index for certification. Second is emphasis on the guide to the students' learning outcomes. According to the requirements of core competence and quality education for graduates, the effectiveness of professional education is evaluated. Third is emphasis on the qualification assessment. Professional certification emphasizes the basic quality requirements for engineering education, as a qualified assessment. Fourth is the emphasis on the continuous quality improvement. The profession must set up a mechanism to improve the quality of education continuously and effectively, and must be evaluated on a regular basis [1-8].

\section{TRAINING TARGET AND PLAN}

Equipment manufacturing industry is the pillar industry in Zhejiang province. In 2012, the output value of the equipment manufacturing industry was 2 trillion dollars, which accounted for $59 \%$ of the total output value. Although Zhejiang is a small resource province, the main economic indicators of the equipment manufacturing industry rank

*Address correspondence to this author at the Mechanical Department, Hangzhou Dianzi University, No. 2 Road, Hangzhou, 310018, China; Tel: 0086-571-86919051; E-mail: chenguojin@163.com third in the country, only behind Shanghai and Jiangsu. For the manufacturing industry of Zhejiang, through extensive operation, technology innovation is the key to further development. Innovative talent is the necessary condition for the rapid and healthy development of Zhejiang. Intelligent manufacture equipment is one of the two key directions of development in Zhejiang province. In 2013 October, the Ministry of industry and information technology approved the Zhejiang province as the first demonstration area for depth fusion of informatization and industrialization in China. To this end, it is proposed to train the engineering technical personnel with mechanical engineering and automation knowledge application ability, the coordinated development of "knowledge, ability, and quality", tamping machine foundation, facing the demand of local industry, which can work in the field of mechanical manufacturing for design and manufacturing, technology development, application study, operation management and sales management and so on.

The above target can be refined into: (1) To master mathematics and natural science, basic knowledge of mechanical engineering discipline, mechanical design, machinery manufacturing, automation and other professional knowledge; (2) With the ability to independently analyze and solve engineering problems, and the ability of strong expression, interpersonal communication, teamwork and cross-cultural communication; (3) With the potential becoming the senior engineering and technical talent of the field and managing and copying with the future, including sound personality and healthy physique, social responsibility and occupation moral, innovation spirit and life-long learning ability and consciousness; (4) Understanding the upgrading and strategic emergence of the industry development direction and main task determined by Zhejiang and the state, with the ability for engaging in 
design and manufacturing, technology development, application study, operation management and sales management in the field of mechanical manufacturing.

In order to reach the goal of the coordinated development of the knowledge, ability and quality, the curriculum system is set up, as shown in Table $\mathbf{1}$.

\section{PRACTICE ARRANGEMENT}

Practice teaching is a very important part of university engineering education. Through practice teaching, the students' awareness of engineering, practice ability and innovation ability can be improved. Moreover, the students can be trained for team cooperation spirit and expression ability, and the comprehensive application of knowledge to solve practical problems. Furthermore, the comprehensive quality can be developed and the ability to adopt practical work can be enhanced, in order to make the students serve society better after graduation. Therefore, profession has always attached great importance to the practical teaching management and reform. At present, the professional practice teaching mainly includes experiments within courses and performances on computer, experiment courses set individually (comprehensive experiment of mechanical creative design, university physics experiment), a separate set of engineering training (metal working training, mechanical mapping training, electronic circuit practice, production practice), independent course designs

Table 1. Main courses on the coordinated development of knowledge, ability and quality.

\begin{tabular}{|c|c|c|}
\hline \multicolumn{2}{|c|}{ Demand of Knowledge, Ability and Quality } & Main Courses to Reach Training Goal \\
\hline \multirow{3}{*}{ Knowledge } & Mathematics and natural science & $\begin{array}{l}\text { (1) Higher mathematics, Linear algebra, Probability and statistics, Methods of numerical computation } \\
\text { (2) College physics, Experiments in college physics } \\
\text { (3) College chemistry }\end{array}$ \\
\hline & $\begin{array}{l}\text { Basic knowledge of mechanical } \\
\text { engineering discipline }\end{array}$ & $\begin{array}{l}\text { (1) Engineering introduction, Theoretical mechanics, Mechanics of materials } \\
\text { (2) Foundation of electrician, Electronic technology, Programming for C language } \\
\text { (3) Engineering materials \& thermo-processing, Thermodynamic engineering, Engineering fluid } \\
\text { dynamics, Hydraulics \& pneumatics }\end{array}$ \\
\hline & $\begin{array}{l}\text { Mechanical design, machinery } \\
\text { manufacturing, automation and } \\
\text { other professional knowledge }\end{array}$ & $\begin{array}{l}\text { (1) Engineering drawing, Principles of machine, Mechanical design, Mechanical control engineering, } \\
\text { Interconvertibility and measurement, Manufacturing engineering, Microcomputer principles and its } \\
\text { applications, Digital control technology, Measurement technique \& signal processing } \\
\text { (2) Electromechanical transmission control, Control system design and simulation (Matlab), Principle } \\
\text { of single-chip computer, Electrical and mechanical system design, Mechanical systems design, Finite } \\
\text { element analysis and CAE software applications, CAD \& CAM for machine manufacturing, Die } \\
\text { design technology, Mechanical design optimization, Computer control technology, Automated } \\
\text { manufacturing systems, Application of electrical control and PLC, Robot technology } \\
\text { (3) All the practice and training, curriculum design, and graduate design }\end{array}$ \\
\hline \multirow{3}{*}{ Ability } & $\begin{array}{l}\text { The ability to independently } \\
\text { analyze and solve engineering } \\
\text { problems }\end{array}$ & $\begin{array}{l}\text { (1) All the teaching classroom discussions, homeworks and experiments } \\
\text { (2) Metalworking practice, Electronic circuit practice, Mechanical mapping training, Mechanism } \\
\text { innovation experiment, Mechanical CAD curriculum design, Curriculum design of microcomputer } \\
\text { interface, Synthetical curriculum design, Production practice, Graduation design } \\
\text { (3) Science and technology innovation practice activity }\end{array}$ \\
\hline & $\begin{array}{l}\text { The ability of strong expression, } \\
\text { interpersonal communication, } \\
\text { teamwork }\end{array}$ & $\begin{array}{l}\text { (1) Grouping experiment and discussion, and classroom Communication and discussion etc. } \\
\text { (2) Grouping tasks, writing instructions and replying in all the practice and training, curriculum design; } \\
\text { technology exchange, writing graduation thesis and replying in graduation design } \\
\text { (3) Science and technology innovation practice activity }\end{array}$ \\
\hline & $\begin{array}{l}\text { The ability of cross-cultural } \\
\text { communication }\end{array}$ & $\begin{array}{l}\text { (1) College English, Professional English (machinery) } \\
\text { (2) Reading and translating foreign literatures in graduation design }\end{array}$ \\
\hline \multirow{3}{*}{ Quality } & $\begin{array}{l}\text { Sound personality and healthy } \\
\text { physique }\end{array}$ & $\begin{array}{l}\text { (1) Physical education, Military training } \\
\text { (2) Cultivation of thought \& morality \& legal basis, College mental health education, Occupation } \\
\text { development and employment guidance of college students, School education, Pre-graduation } \\
\text { education }\end{array}$ \\
\hline & $\begin{array}{l}\text { Social responsibility and } \\
\text { occupation morale }\end{array}$ & $\begin{array}{l}\text { (1) Modern Chinese history program, Cultivation of thought \& morality \& legal basis, Introduction to } \\
\text { Mao Zedong's thought and the theoretical system of socialism with China characteristics, The basic } \\
\text { principles of Marxism, Situation and policies, Military theory, School education, Pre-graduation } \\
\text { education } \\
\text { (2) Practice of political courses } \\
\text { (3) Social practice parts in production practice, Graduation design, Science and technology innovation } \\
\text { practice activity }\end{array}$ \\
\hline & $\begin{array}{l}\text { Innovation spirit and life-long } \\
\text { learning ability and } \\
\text { consciousness }\end{array}$ & $\begin{array}{l}\text { (1) Innovation design part in all the curriculum design and graduation design } \\
\text { (2) Homework and thinking part in all the courses } \\
\text { (3) Science and technology innovation practice activity }\end{array}$ \\
\hline
\end{tabular}


(mechanical CAD curriculum design, computer interface curriculum design, mechanical manufacturing engineering curriculum design, comprehensive curriculum design), innovation practice, graduation design, extracurricular practice education (practice of political course) and extracurricular technological innovation activities.

In order to meet the requirements of practice teaching, the profession relies on the comprehensive engineering education advantages in our university, such as electronic circuit practice using state demonstration center of electrical and electronic experimental teaching. On the other hand, the profession relies on the two provincial demonstration centers of mechanical engineering and industrial product design experimental teaching. The following are the professional laboratories and practice bases.

(1) The curriculum labs: the major labs are mechanics lab, mechanical principle and design lab, test technology lab, numerical control technology lab, heat treatment lab, precision measurement lab, MCU lab, hydraulic and pneumatic lab, mechanical CAD lab and other kinds of course labs. These can better meet the experimental and computing requirements for the professional students in class.

(2) The metalworking practice base: it can provide good practice condition for mechanical engineering basic training, independent and creative experiments, etc. In recent years, the profession has initiated four
Zhejiang province finance laboratory construction projects such as the "comprehensive engineering training base for modern engineering education". This has further improved experimental and engineering training condition.

(3) The practice bases outside university: the profession has established the one state practice education base outside university and the two state engineering practice education centers. By combining provincial science and technology innovation service platform, the provincial key laboratories and enterprise practice bases, the characteristic industry practice bases outside university are established. At the same time, by means of cooperation in scientific research and social service, a number of cooperative education agreements with enterprises are signed. Through practice bases outside university, a good foundation of production practice and graduation practice for students is provided. The off-campus practice bases are shown in Fig. (1).

(4) The students' activity center for science and technology innovation practice: the center is equipped with various kinds of small machine tools, such as lathes, milling machines, and drilling machines, and Fischer creative combination platform facilities. That can satisfy the students' requirements for science and technology innovative design and processing, and

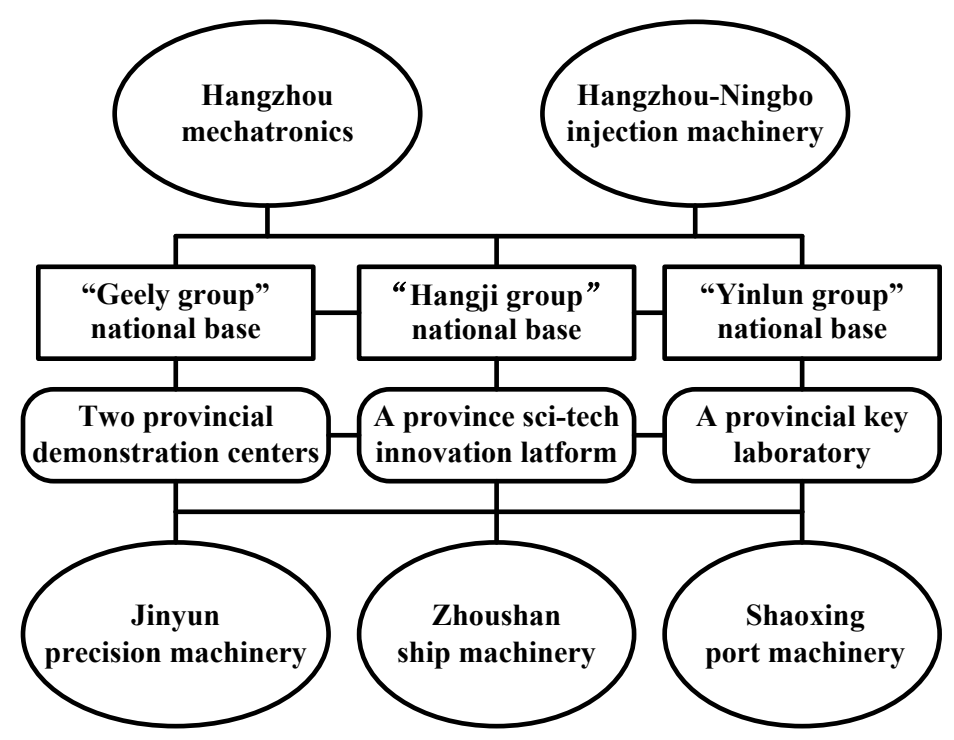

Fig. (1). The off-campus practice bases.

Table 2. Social evaluation of teaching effect.

\begin{tabular}{|c|c|c|c|}
\hline Survey Method & Coverage & When & Result \\
\hline Graduates' informal discussions & $5 \%$ & From 2009, annually & Notes of meeting \\
\hline Enterprise surveys & & From 2009, annually & Research proposal \\
\hline Informal discussions for industry and enterprise experts & & From 2011, annually & Notes of meeting \\
\hline QQ groups & $50 \%$ & From 2010, occasionally & QQ notes \\
\hline
\end{tabular}


provide good conditions for the students' extracurricular engineering practice.

\section{INTEGRATED PLATFORM OF CYBER PHYSICAL SYSTEM BASED ON INDUSTRY 4.0}

Entering into the twenty-first century, the information and communication technology has made breakthrough progress. The intelligent network world and the physical world are fused to produce the internet of things and the cyber physical system. Therefore, the German first used the cyber physical system for the manufacturing industry, and opened it forth the industrial revolution of industry 4.0 . The induction of the cyber physical system into the manufacturing and logistics fields, as well as the use of the internet of things and its services in the industrial process, result in innovative industry, that is, intelligent industry. Totally different from the automation system in the traditional factory, the intelligent plant uses the serviceoriented architecture, as shown in Fig. (2). As it can be seen from Fig. (2), corresponding to the field level in the traditional automation system, it uses the technology of the internet of things; corresponding to the control level, it uses the cyber physical production system (CPPS); corresponding to the monitoring and management level, it uses the service internet to provide service by connecting to a safe reliable and credible cloud network.

Taking the "big engineering" of the modern manufacturing industry as the main line, combining the mechatronic system with the integration process of management and control, the comprehensive practice of electromechanical engineering is highlighted, and the ability of "creativity, innovation and entrepreneurship" and the comprehensive practical ability for students are promoted. The education mode and practice teaching system of modern manufacturing industry refers the student as the main body, the comprehensive knowledge of modern manufacturing industry as the background, and the cultivation of students' comprehensive practice ability as the core in stages and in mutually promoting and modular types. According to the training scheme of the college students' creativity, innovation and entrepreneurship, the experimental platform is set up. In order to highlight the intelligent manufacturing technology, the intelligent manufacturing system integrated by machine, electronics, control and management is developed, as shown in Fig. (3). Creating the modern manufacturing engineering experiments based on industry 4.0 for training the students to be "excellent engineers" acquiring forward-looking vision, incorporating the industry 4.0 concept, and the integration of the industry and information, the intelligent plant experimental system can be produced based on the industry 4.0 to provide the experimental platform for future industry, as shown in Fig. (4).

\section{QUALITY MONITORING AND EVALUATION}

The professional teaching quality monitoring system includes quality control, supervision, feedback and analysis of teaching process, and the external evaluation. The quality control of teaching process is implemented mainly by the teachers according to the requirements of the teaching quality control point. Its responsible persons are teachers, and the examiner is the colleges' management. Quality supervision of teaching process is mainly composed of attending lectures, teaching examinations and students' evaluations of teaching. Examiners are the main office of educational administration and college. The quality feedback of teaching process is operated mainly by monitoring departments, college teachers and students. The quality analysis of teaching process is executed by office of educational administration, college, office of student affairs and teachers. The curriculum goals, teaching achievements, teaching resources, students' comprehensive ability, the quality of the graduates, and students' learning status are analyzed and evaluated.

On this basis, the graduates' informal discussions, online questionnaires, QQ groups, and enterprise surveys evaluate the teaching effect, as shown in Table 2. According to the internal and external evaluation results regarding the teaching quality, and the national, social, and employing unit demands, the need is to modify the training target, graduation requirements and teaching plan. The quality control mechanism of the concrete teaching process is shown in Fig. (5).

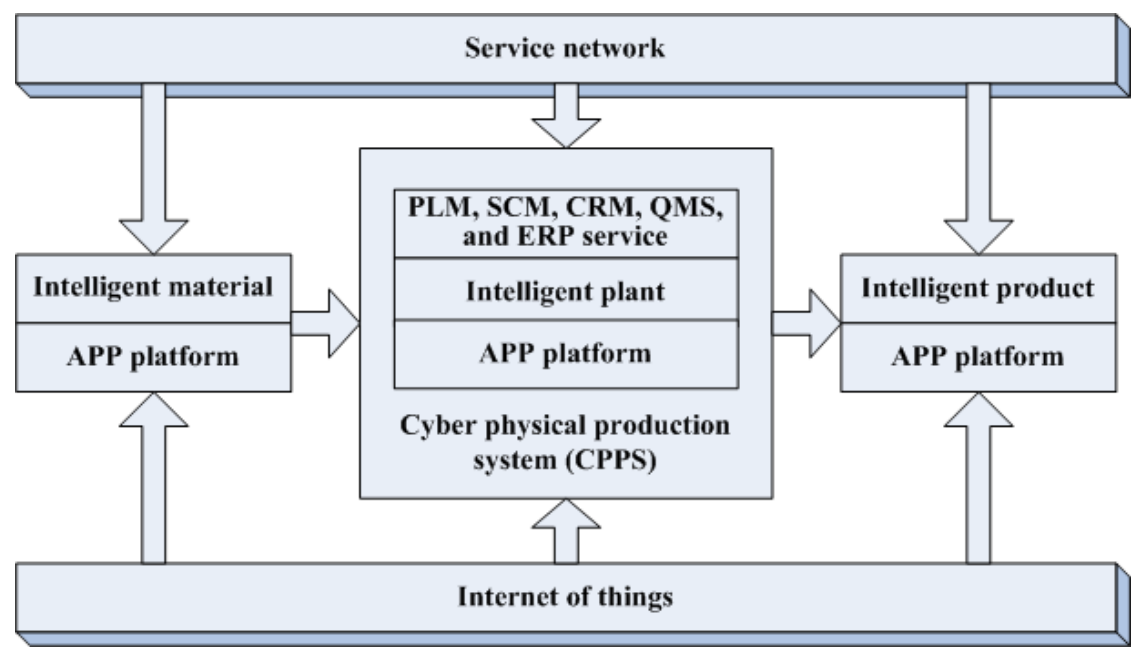

Fig. (2). Systemic architecture of intelligent plant. 


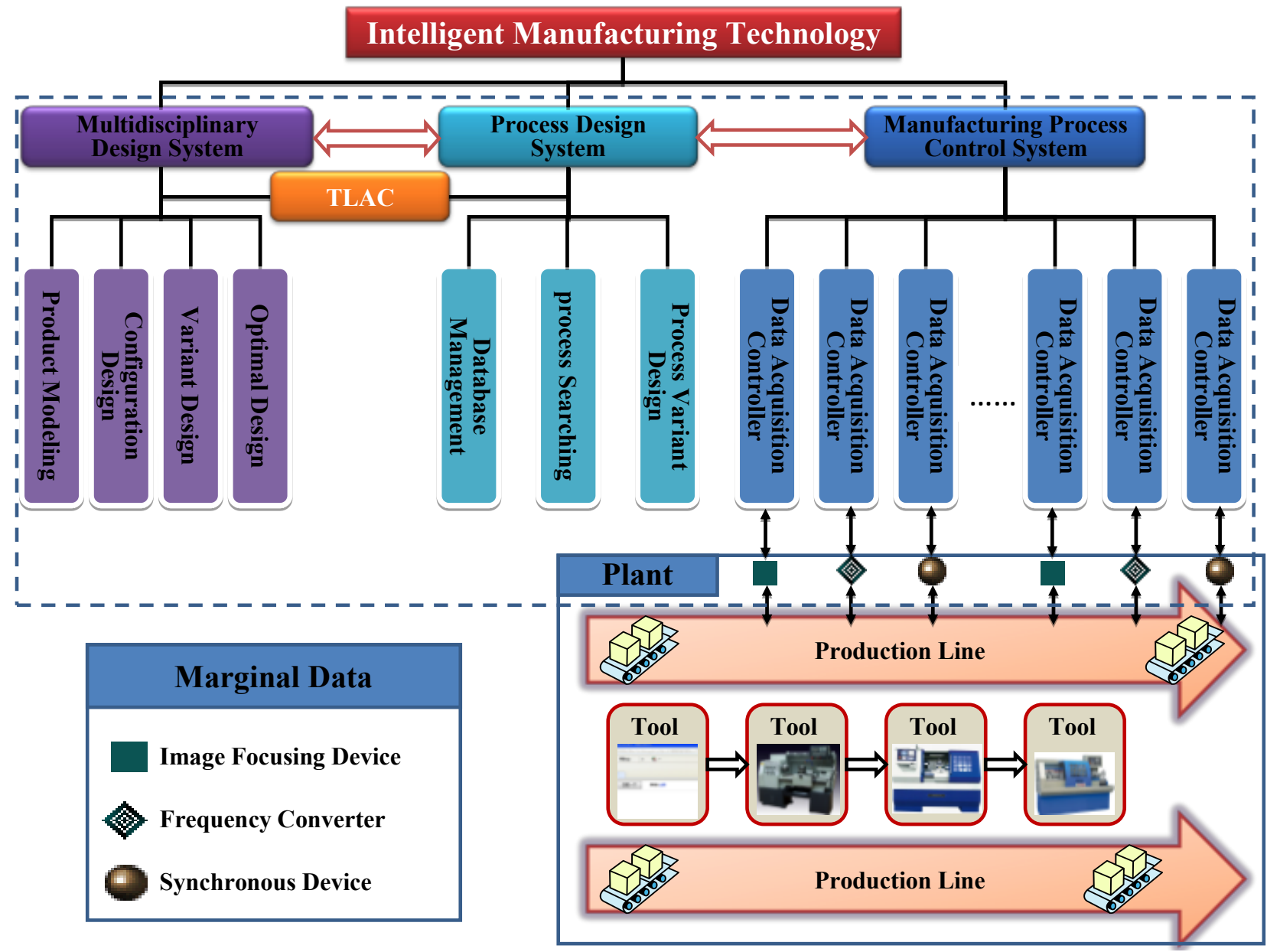

Fig. (3). Systemic architecture of intelligent manufacturing system.

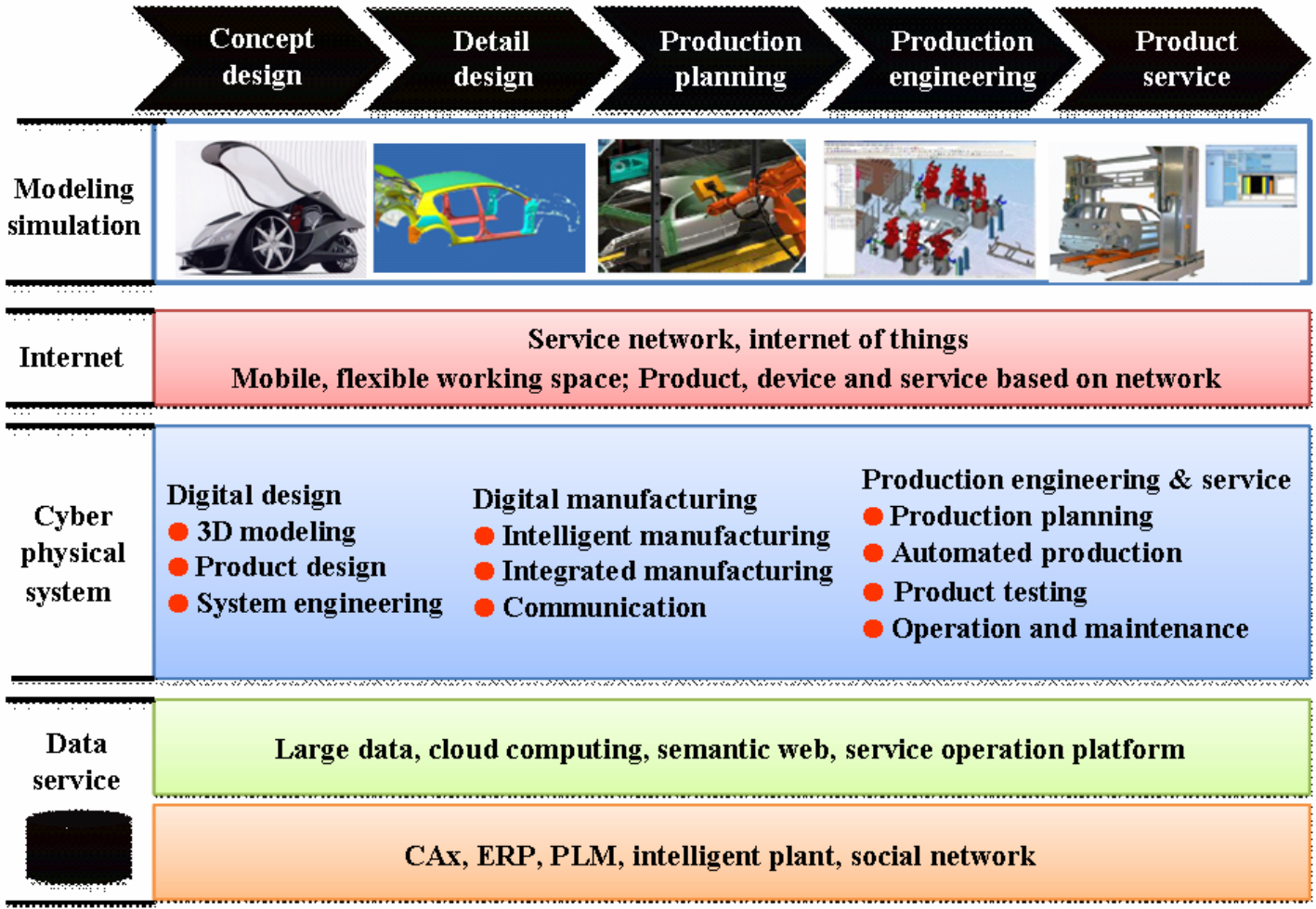

Fig. (4). Systemic architecture of intelligent plant experimental system. 
Teaching feedback 1

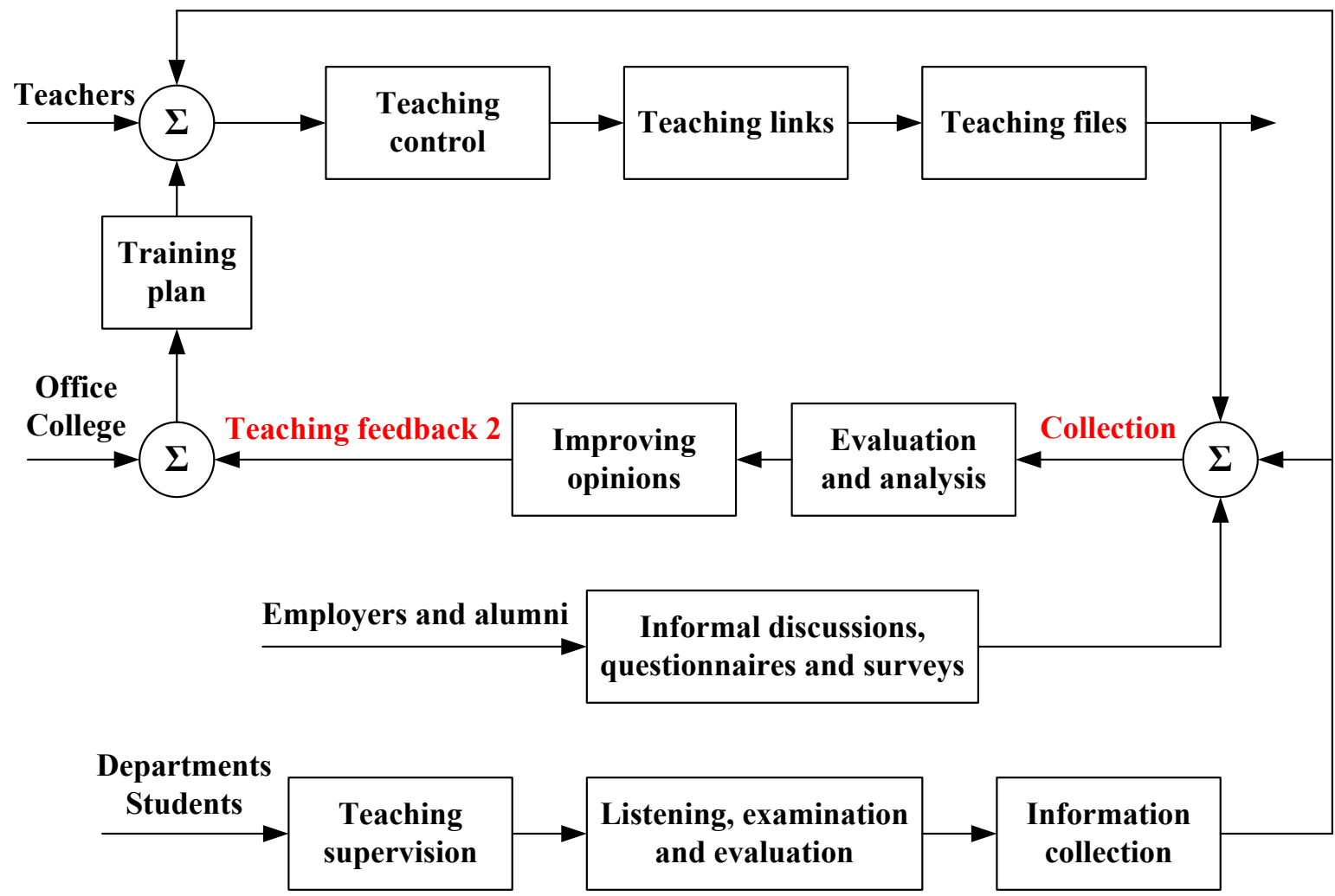

Fig. (5). Quality control mechanism of teaching process.

\section{CONTINUOUS IMPROVING MECHANISM}

Since 2008, the training goal has been considered as the breakthrough point, and a complete system with two closed loops composed of students, graduation requirements, continuous improvements, curriculum systems, and supporting conditions. A mechanism for continuous improvement has formed. Through this, a well-behaved cycle has been formed that could continuously improve the quality of engineering education, as shown in Fig. (6).

The top-level design, namely the training plan, includes training objectives, graduation requirements and course system. The machinery professional training target is segmented into 4 goals. Goal 1: Mathematics and natural science, mechanical engineering discipline and professional knowledge; Goal 2: the ability to analyze and solve problems independently, and the ability of expression, interpersonal communication, teamwork and cross-culture communication; Goal 3: the potential to manage and cope with future, including physical quality, social responsibility and occupation morale, and the spirit of innovation and life-long learning ability and consciousness; Goal 4: for the Zhejiang and state industry, the ability to engage in mechanical engineering and other aspects of the work. On the basis of the 4 goals mentioned above, 12 specific graduation requirements are put forward. According to the graduation requirements, the courses are set up, which include the humanities and social sciences, mathematics and natural sciences, engineering bases, professional bases, professional courses, practice links, extracurricular education and learning guidance. The graduation requirements have a relation matrix corresponding to the target, and also have a relationship matrix with the curriculum system. In Fig. (6), teaching activities in the curriculum system are monitored to inspect teaching and learning. When the students do not reach the requirements of a certain course, they can recycle to make-up examination or retake classes. Teachers can understand teaching situation through feedback, and may improve the teaching environment and methodology. The support conditions comprise of teachers, experiment and library resources, funding, teaching facilities, management system, off-campus bases and teachers, for supporting the course system and teaching activities. University and college established the continuous improvement mechanism for improving the conditions, and through feedback, formed the teaching quality model with double closed loops as an education plan revision.

\section{CONCLUSION}

The personnel culturing target proposed in 2008, presented the concept of integrated and coordinated development of "knowledge, ability, and quality". The Zhejiang province economy and the equipment manufacturing industry occupy half of the total. According to this feature and the talent demand for Zhejiang creating advanced manufacturing equipments, we base in Zhejiang, service for zhejiang, face to the country in the talent cultivation orientation of the training objectives, curriculum designs, and graduation requirements. The direction module courses on "mechanical and electrical integration" and 


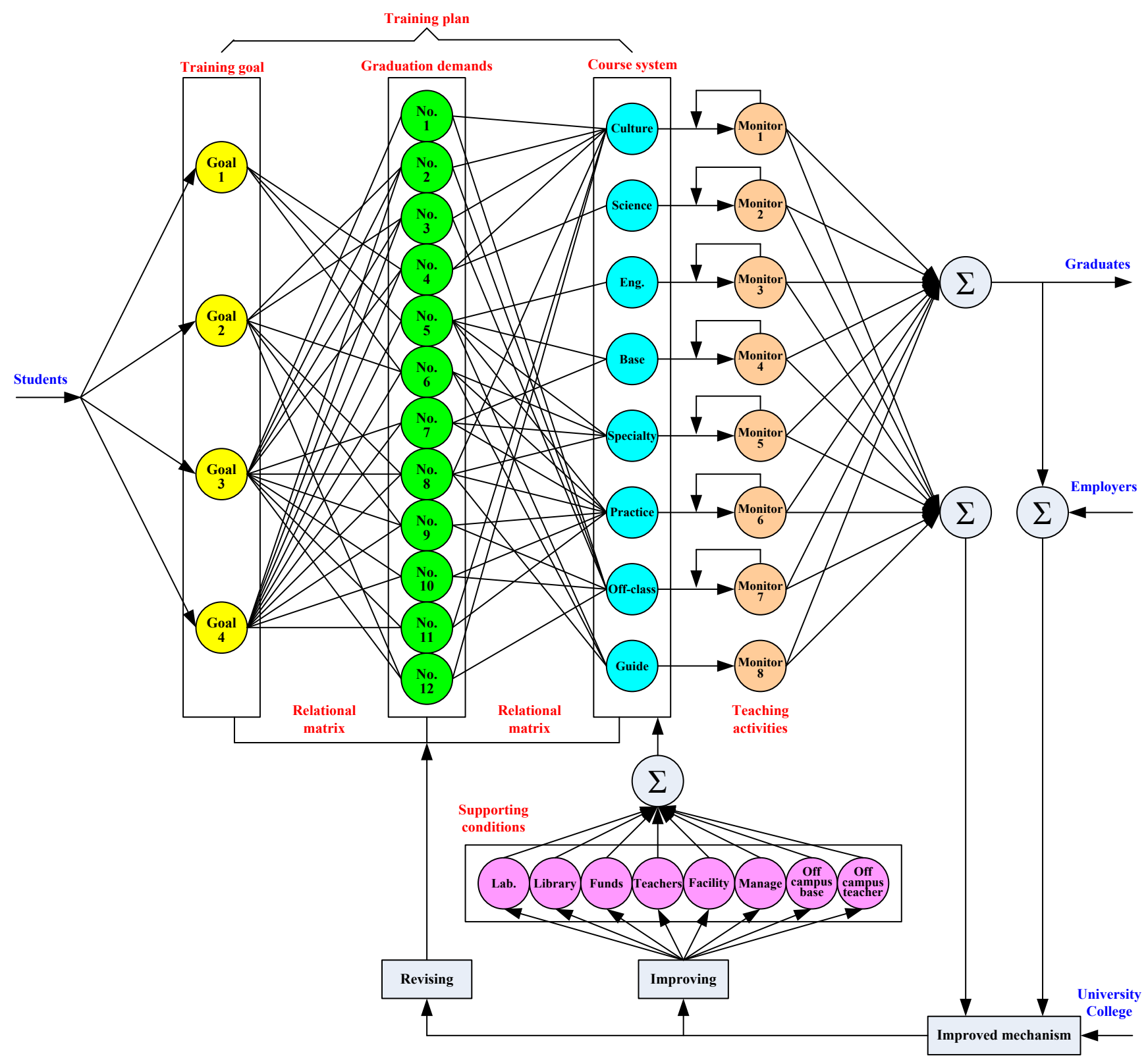

Fig. (6). A complete system with two closed loops.

"digital design" are launched, and the die design courseis added. Based on the evaluation feedbacks of employers and alumni, according to the change of national education development and the demand for talent in Zhejiang province, the training plan was improved a lot respectively in 2010 and 2013. At the same time, the "excellent engineer" training programs of the 2011-2013 years were developed. In 2009, the provincial experimental teaching demonstration center was constructed. At the same time, the model on cultivating talents of mechanical engineering in the CDIO engineering education mode was studied, and the demonstration in part of courses was developed. In 2010, in order to adapt to the engineering education plan of the "excellent engineer", the agreements for joint training were signed with more than 20 enterprises in Zhejiang province. At the same time, 3 national practice bases outside university were declared, and the projects were approved by the Ministry of education. In
2011 , initial efforts were made for the implementation of the "excellent engineer" training program.

Since 2008, after the integration development of "knowledge, ability and quality", and the implementation of the training objective for Zhejiang province industrial demand, the "student-centered and output-guided" concept was further established, and the experts of industry and enterprise were invited to discuss the training objective and curriculum system. The practice links are strengthened, and the good results are achieved. Especially in order to extend participation in academic competition, and to further improve the quality and ability of the students, since 2011, the mechanical discipline competition conducted jointly by the university, Zhejiang society of mechanical engineering, and Hangzhou society of mechanical engineering is being carried out. This is the first time in our province that the mechanical comprehensive discipline competition has been 
Table 3. The competitions and employment rates.

\begin{tabular}{|c|c|c|c|c|}
\hline Year & State Awards & Province Awards & Society Awards & Employment Rates (\%) \\
\hline \hline 2011 & 6 & 19 & 25 & 99.40 \\
\hline 2012 & 8 & 24 & 35 & 98.08 \\
\hline 2013 & 11 & 13 & 28 & 98.61 \\
\hline
\end{tabular}

carried out, which is cooperated by the university with the societies. More than $80 \%$ of students participated in the competition. It has widened the participation range to improve the students' innovation consciousness and practical ability. The student employment rate now remains at $98 \%$, and the employing units have given out a high evaluation. The competitions and employment rates of the students in the recent 3 years are shown in Table 3 .

\section{CONFLICT OF INTEREST}

The authors confirm that this article content has no conflict of interest.

\section{ACKNOWLEDGEMENTS}

This work is supported by the provincial education reform project (No. jg2013061) and the university education reform project (No. ZD1301).

\section{REFERENCES}

[1] C. Guojin, C. Zhiping, H.X.W. Wanqiang, N. Jing, S. Shaohui, and G. Youping, "Study on the teaching mode of cognitioncomprehension with protrude in two ends for mechanical specialty," In: Proceedings of ICETT, 2010.

[2] C. Guojin, C. Zhiping, H.X.W. Wanqiang, N. Jing, S. Shaohui, and G. Youping, "Experiment platform, special item and ability development on creativity, innovation and entrepreneurship," In: Proceedings of ICETT, 2010.

[3] C. Guojin, "Study on the education plan of the creativity, innovation and entrepreneurship ability in university students" In: Proceedings of ICCIC, 2011.

[4] C. Guojin, "Study and practice on training scheme of university students' entrepreneurship ability" In: Proceedings of ICCIC, 2011.

[5] C. Guojin, "Mechanical engineering student's creative training and their innovative ability cultivation", Journal of Hangzhou Dianzi University (Social Sci.), vol. 6, pp. 63-66, 2010.

[6] C. Guojin, "On innovative teaching practice of engineering university students", Research and Exploration in Laboratory, vol. 29, pp. 95-97, 2010.

[7] C. Guojin, "Study on training students with innovative ability", Journal of Hangzhou Dianzi University (Social Science), vol. 4, pp. 60-63, 2008

[8] C. Guojin, L. Zhihua, and L. Qingmin, "Research on engineering practice teaching system featured by information and economics and management", Experimantal Technology and Management, vol. 25 , pp. $17-19,2008$ 